\title{
BENDA ASING ESOFAGUS DI BAGIAN/SMF THT-KL BLU RSUP PROF. Dr. R. D. KANDOU MANADO PERIODE JANUARI 2010 - DESEMBER 2014
}

\author{
${ }^{1}$ Siti N. Marasabessy \\ ${ }^{2}$ Steward K. Mengko \\ ${ }^{3}$ Ora I. Palandeng \\ ${ }^{1}$ Kandidat Skripsi Fakultas Kedokteran Univerversitas Sam Ratulangi Manado \\ ${ }^{2}$ Bagian THT-KL Fakultas Kedokteran Universitas Sam Ratulangi Manado \\ Email: n.marasabessy@yahoo.com
}

\begin{abstract}
Esophageal foreign body is sharp or blunt objects or food stuck and stuck in the esophagus due to ingested, either deliberately or accidentally. Esophagoscopy extraction is the common treatment. This study aimed to obtain the occurance of foreign bodies in esophagus in the THT-KL RSUP Prof. Dr. R. D. Kandou Manado during period January 2010-December 2014, and the pattern of age, gender, and type of foreign bodies that impact esophageal foreign bodies. This study used descriptive-retrospective. Samples were all patients who seek treatment in the THT-KL RSUP Prof. Dr. R. D. Kandou Manado diagnosed as esophageal foreign body, during period January 2010-December 2014. Fivety-two patients had diagnose with esophageal foreign bodies during period January 2010. The group of age 0-10 years had a highest number of patients with 17 cases (32.7\%). There was no different between male (25 patients) and female (27 patients). The most common esophageal foreign bodies in all patient was dentures with 25 cases $(48.1 \%)$ and coins become the second most common foreign bodies in 18 cases (34.6\%). Conclusion: The number of patients with esophageal foreign bodies was a small part of the total number of THT-KL cases because these cases were more incidental.
\end{abstract}

Keywords: foreign bodies. esophagus. esophagoscopy.

\begin{abstract}
Abstrak: Benda asing esofagus adalah benda yang tajam maupun tumpul atau makanan yang tersangkut dan terjepit di esofagus karena tertelan, baik secara sengaja maupun tidak sengaja. Penatalaksaan yang lazim adalah esofagoskopi ekstraksi untuk mengeluarkan benda asing. Tujuan penelitian ini adalah untuk mengetahui angka kejadian benda asing esofagus di Bagian/SMF THT-KL RSUP Prof. Dr. R. D. Kandou Manado mulai bulan Januari 2010Desember 2014 dan untuk mengetahui jenis kelamin, golongan umur dan jenis benda asing tersering dalam kasus benda asing esofagus. Penelitian ini menggunakan metode deskriptifretrospektif. Sampel penelitian adalah semua penderita yang berobat di Bagian/SMF THT-KL RSUP Prof. Dr. R. D. Kandou Manado yang terdiagnosis sebagai benda asing esofagus, mulai bulan Januari 2010-Desember 2014. Lima puluh tiga pasien telah terdiagnosis sebagai benda asing esofagus selama periode Januari 2010-Desember 2014. Golongan umur 0-10 tahun adalah yang paling banyak menjadi pasien benda asing esofagus dengan 17 kasus (32,7\%). Tidak ada perbedaan yang cukup berarti antara pasien pria (25 pasien) dan perempuan (27 pasien). Benda asing tersering yang menjadi penyebab benda asing esofagus adalah gigi palsu dengan 25 kasus $(48,1 \%)$ dan uang logam menjadi benda asing tersering kedua dengan 18 kasus (34,6\%). Simpulan : Penderita benda asing esofagus memiliki jumlah yang sedikit dari jumlah keseluruhan kasus THT-KL, karena kasus ini lebih bersifat insiden.
\end{abstract}

Kata kunci: benda asing, esofagus, esofagoskopi 
Benda asing esofagus adalah benda yang tajam maupun tumpul atau makanan yang tersangkut dan terjepit di esofagus karena tertelan, baik secara sengaja maupun tidak sengaja. Peristiwa tertelan dan tersangkutnya benda asing merupakan masalah utama pada anak usia 6 bulan sampai 6 tahun dan dapat terjadi pada semua umur pada tiap lokasi di esofagus, baik di tempat penyempitan fisiologis maupun patologis dan dapat pula menimbulkan komplikasi fatal akibat perforasi. $^{1}$

Benda asing yang tersangkut pada esofagus biasanya ditemukan pada 4 tempat penyempitan fisiologi pada esofagus yaitu cincin krikofaringeal, persilangan antara esofagus dan arkus aorta, persilangan esofagus dengan bronkus utama sinistra, dan sfingter bawah. Gejala yang biasanya timbul seperti, disfagia, pirosis, odinofagi dan regurgitasi. ${ }^{2}$

Faktor predisposisi antara lain belum tumbuhnya gigi molar untuk dapat menelan dengan baik, koordinasi proses menelan dan sfingter laring yang belum sempurna pada kelompok usia 6 bulan sampai 1 tahun, retardasi mental, gangguan pertumbuhan dan penyakit-penyakit neurologik lain yang mendasarinya. Pada orang dewasa tertelan benda asing sering dialami oleh pemabuk atau pemakai gigi palsu yang telah kehilangan sensasi rasa (tactile sensation) dari palatum, pada pasien gangguan mental dan psikosis. ${ }^{1,3}$ Selain itu juga, kebiasaan misalkan "memegang" dengan gigi benda-benda seperti uang logam, mainan dan lain-lain. ${ }^{3}$

Angka kejadian tertelan benda asing mengakibatkan 1500 kematian di Amerika Serikat. Sebanyak 80-90 \% benda asing esofagus akan melewati saluran pencernaan selama 7-10 hari tanpa komplikasi, sedangkan $10-20 \%$ sisanya membutuhkan tindakan endoskopi dan 1\% membutuhkan pembedahan. Sebanyak $75 \%$ benda asing saluran cerna berada di esofagus saat terdiagnosis. ${ }^{4,5}$

Dilaporkan 24 kasus migrasi benda asing esofagus pada leher. Semua benda asing tersebut adalah benda tajam.
Dilaporkan 4 kasus benda asing tulang ikan yg menimbulkan perforasi esofagus servikal dan ditemukan pada regio subkutan leher atau bermigrasi pada kelenjar tiroid di mana 3 kasus berhasil dengan eksplorasi dan 1 kasus lagi dengan lobektomi. $^{5,6}$

Di Indonesia khususnya di RSUP $\mathrm{H}$. Adam Malik Medan penelitian pada tahun 2010, dari 110 kasus penelitian yang didapat sebagian besar penderita berjenis kelamin laki-laki sebanyak 69 orang (62,7\%), berdasarkan umur kelompok anak-anak merupakan yang paling banyak adalah sebanyak 61 orang (55,5\%), sedangakan kapas merupakan jenis benda asing yang paling banyak ditemukan sebanyak 29 kasus (26,4\%), dan benda asing terbanyak adalah benda asing non organik yaitu sebanyak 79 kasus (71,8\%), terakhir menurut lokasi benda asing yang terbanyak berada pada telinga yaitu sebanyak 47 kasus $(42,7 \%)^{7}$

Tujuan dari penelitian ini untuk mengetahui distribusi umur, jenis kelamin dan jenis benda asing esofagus di Bagian/SMF THT-KL RSUP Prof. Dr. R. D. Kandou Manado mulai bulan Januari 2010-Desember 2014.

\section{METODE PENELITIAN}

Penelitian ini menggunakan metode deskriptif-retrospektif. Data berasal dari status penderita, buku register dan buku laporan operasi pasien di Bagian/SMF THT-KL RSUP Prof. Dr. R. D. Kandou Manado. Waktu penelitian dilakukan pada bulan Oktober - Desember 2014. Tempat penelitian dilakukan di Bagian/SMF Ilmu Kesehatan THT-KL dan BLU RSUP Prof. Dr. R. D. Kandou Manado.

Sampel penelitian adalah semua penderita yang berobat di Bagian/SMF THT-KL RSUP Prof. Dr. R. D. Kandou Manado yang terdiagnosis sebagai benda asing esofagus, mulai bulan Januari 2010Desember 2014. Variable penelitian diantaranya jenis kelamin, umur, jenis benda asing, dan lokasi benda asing. 


\section{HASIL PENELITIAN}

Berdasarkan hasil penelitian yang dilakukan terhadap penderita benda asing esofagus di Bagian/SMF THT-KL RSUP Prof. DR. R. D. Kandou periode Januari 2010 - Desember 2014 diperoleh data yang disajikan dalam bentuk tabel distribusi frekuensi. Dalam kurun waktu 5 tahun yaitu 2010-2014 didapatkan kasus benda asing esofagus sejumlah 52 kasus.

Tabel 1. Jumlah kasus benda asing esofagus selang waktu $2010-2014$

\begin{tabular}{ccc}
\hline Tahun & $\mathrm{n}$ & $\%$ \\
\hline 2010 & 5 & 9,6 \\
2011 & 10 & 19,2 \\
2012 & 5 & 9,6 \\
2013 & 16 & 30,8 \\
2014 & 16 & 30,8 \\
Total & 52 & 100 \\
\hline
\end{tabular}

Berdasarkan Tabel 1, dapat dilihat insiden benda asing esofagus dengan jumlah total 52 kasus, tahun 2010 ditemukan kasus benda asing esofagus sebanyak 5 kasus, tahun 2011 sebanyak 10 kasus, tahun 2012 sebanyak 5 kasus, tahun 2013 sebanyak 16 kasus dan tahun 2014 sebanyak 16 kasus.

Tabel 2. Penderita benda asing esofagus berdasarkan golongan umur selang waktu $2010-2014$

\begin{tabular}{ccc}
\hline Gol. Umur & $\mathrm{n}$ & $\%$ \\
\hline $0-10$ & 17 & 32,7 \\
$11-20$ & 6 & 11,5 \\
$21-30$ & 4 & 7,7 \\
$31-40$ & 2 & 3,8 \\
$41-50$ & 11 & 21,2 \\
$>51$ & 12 & 23,1 \\
Total & 52 & 100 \\
\hline
\end{tabular}

Berdasarkan Tabel 2, dapat dilihat bahwa golongan umur 0-10 tahun merupakan penderita terbanyak dengan 17 kasus. Kemudian golongan umur $>51$ tahun dengan 12 kasus, setelah itu golongan umur 41-50 tahun dengan 11 kasus, golongan umur 11-20 tahun dengan 6 kasus, gologan umur 21-30 tahun dengan 4 kasus, dan golongan umur 31-40 tahun dengan 2 kasus.

Tabel 3. Penderita benda asing esofagus berdasarkan jenis kelamin selang waktu 2010 2014

\begin{tabular}{ccc}
\hline Jenis Kelamin & $\mathrm{n}$ & $\%$ \\
\hline Laki-laki & 25 & 48,1 \\
Perempuan & 27 & 51,9 \\
Total & 52 & 100 \\
\hline
\end{tabular}

Berdasarkan Tabel 3, dapat dilihat penderita benda asing esofagus memiliki perbandingan yang tidak jauh berbeda yaitu 25 kasus pada laki-laki dan 27 kasus pada perempuan.

Tabel 4. Jenis benda asing yang ditemukan selang waktu 2010 - 2014

\begin{tabular}{ccc}
\hline $\begin{array}{c}\text { Jenis Benda } \\
\text { Asing }\end{array}$ & $\mathrm{n}$ & $\%$ \\
\hline Gigi Palsu & 25 & 48,1 \\
Uang Logam & 18 & 34,7 \\
Jarum & 3 & 5,8 \\
Tulang & 1 & 1,9 \\
Cincin & 1 & 1,9 \\
Plastik & 1 & 1,9 \\
Daging & 1 & 1,9 \\
Mata Kalung & 1 & 1,9 \\
Besi Magnet & 1 & 1,9 \\
Total & 52 & 100 \\
\hline
\end{tabular}

Berdasarkan tabel 4, dapat dilihat bahwa ditemukan jenis benda asing yang paling sering menyebabkan kasus benda asing esofagus adalah gigi palsu sebanyak 25 kasus, uang logam sebanyak 19 kasus, jarum sebanyak 3 kasus, dan yang paling sedikit ditemukan adalah tulang, cincin, plastik, daging babi, mata kalung dan besi magnet masing-masing sebanyak 1 kasus.

\section{BAHASAN}

Pada penelitian ini sampel penelitian adalah penderita baru yang berobat di Bagian/SMF THT-KL RSUP Prof. Dr. R. D. Kandou Manado yang terdiagnosis sebagai benda asing esofagus, mulai dari Januari 2010 - Desember 2014 sebanyak 52 kasus. 
Frekuensi kasus tiap tahunnya bervariasi. Bervariasinya kasus benda asing esofagus ini dikarenakan oleh factor personal misalnya umur, jenis kelamin, pekerjaan, kondisi, sosial dan tempat tinggal, faktor kejiwaan seperti emosi dan ganggguan psikis. ${ }^{10}$

Faktor kewaspadaan orang tua dalam mengawasi anaknya terhadap benda-benda yang dapat dimasukkan kedalam mulut anak. Hal ini sebenarnya dapt dicegah dengan mempersiapkan makanan dengan baik dan meletakkan benda-benda kecil yang tidak dapat dimakan jauh dari jangkauan anak-anak. Pada orang tua kasus benda asing dapat terjadi karena kecerobohan saat makan, saat bicara, atau saat tertawa yang menyebabkan benda asing dapat tertelan, dalam hal ini paling sering gigi palsu. ${ }^{10}$

Dari hasil penelitian mengenai penderita benda asing esofagus berdasarkan golongan umur, bahwa didapatkan golongan umur 0-10 tahun merupakan golongan umur yang terbanyak ditemukannya benda asing esofagus yaitu sebanyak 17 kasus. Hal ini disebabkan karena adanya fase oral pada anak cenderung sering memasukkan bendabenda yang ada disekitarnya kedalam mulut. ${ }^{8}$ Selain itu penyebabnya antara lain belum tumbuhnya gigi molar untuk dapat menelan dengan baik, koordinasi proses menelan dan sfingter laring yang belum sempurna pada kelompok usia 6 bulan sampai 1 tahun. $^{1}$

Pada orang dewasa paling banyak ditemukan pada golongan umur $>51$ tahun sebanyak 12 kasus. Ada beberapa faktor yang mungkin menjadi penyebab antara lain makan sambil bicara atau tertawa, kurang berhati-hati tidak memperhatikan adanya tulang dan benda-benda yang dapat dimakan pada makanan mereka, selain itu kasus benda asing esofagus ini juga sering dialami oleh pemabuk, pemakain gigi palsu, atau penderita gangguan mental atau psikosis. ${ }^{11}$

Pada Tabel ketiga mengenai benda asing esofagus berdasarkan jenis kelamin, didapatkan bahwa ada perbedaan jumlah namun tidak terlalu mencolok yaitu lakilaki dengan 25 kasus dan perempuan dengan 27 kasus. Pada kasus benda asing esofagus dapat dilihat bahwa jenis kelamin tidaklah terlalu berpengaruh pada angka kejadian benda asing esofagus.

Pada tabel keempat mengenai jenis benda asing tersering yang ditemukan pada kasus benda asing esofagus adalah gigi palsu sebanyak 25 kasus. Sedangkan urutan kedua terbanyak adalah uang logam sebanyak 18 kasus. Benda asing ini dapat tersangkut di esofagus karena kecerobohan saat makan, saat bicara, atau saat tertawa yang menyebabkan benda asing dapat tertelan. $^{10}$

Gigi palsu yang tertelan juga bisa diakibatkan karena makanan yang keras, mengunyah makanan dengan terlalu cepat, serta ketidakpatuhan untuk memeriksakan gigi palsu ke dokter gigi. Sebuah studi di Nigeria tentang kasus gigi palsu esofagus menyimpulkan bahwa kebanyakan pasien gigi palsu dalam esofagus di Afrika, memiliki riwayat tidak pernah memeriksakan gigi palsunya ke dokter gigi sejak awal pemasangan gigi palsu. ${ }^{11}$

Koin adalah benda asing yang paling umum ditelan pada kelompok usia anak. Kurang perhatiannya orang tua dalam mengawasi anak dalam bermain merupakan faktor resiko yang paling penting dalam kasus ini. ${ }^{12}$

Penatalaksanaan yang lazim adalah mengambil benda asing tersebut dengan esofagoskop langsung. Esofagoskop dapat dilakukan dalam anestesi lokal atau umum. Pilihan anestesi dan esofagoskop tergantung pada ahli endoskopi, usia dan umumnya kesehatan pasien, serta penyakit dicurigai. $^{9}$ Foto rontgen harus diulang sebelum tindakan untuk memastikan bahwa benda asing tersebut belum masuk ke lambung atau telah dimuntahkan. Bila benda asing telah berhasil dikeluarkan harus dilakukan esofagoskopi ulang untuk menilai adanya kelainan-kelainan esofagus yang telah ada sebelumnya. ${ }^{1}$ 


\section{SIMPULAN}

Berdasarkan hasil penelitian dan pembahasan, maka dapat disimpulkan bahwa penderita benda asing esofagus memiliki jumlah yang sedikit dari jumlah keseluruhan kasus THT-KL, karena kasus ini lebih bersifat insiden. Golongan umur 010 tahun merupakan golongan umur yang paling sering ditemukan benda asing dalam esofagus. Karena kecenderungan anak untuk memasukkan benda dalam mulutnya. Pada orang dewasa lebih sering ditemukan pada golongan umur $>51$ tahun. Perbandingan angka kejadian antara lakilaki dan perempuan tidak terlalu mencolok yaitu 25 kasus pada laki-laki dan 27 kasus pada perempuan. Benda asing tersering yang ditemukan pada kasus benda asing esofagus adalah gigi palsu sebanyak 25 kasus. Diikuti dengan uang logam sebanyak 18 kasus.

\section{SARAN}

Berdasarkan kesimpulan tersebut, maka dapat diberikan saran bahwa perlu adanya pemberian informasi yang baik tentang benda asing esofagus kepada masyarakat umum khususnya para orang tua agar lebih berhati-hati dalam hal menjaga anak sehingga tidak sembarangan memasukkan benda ke dalam mulut. Kiranya penelitian tentang benda asing esofagus ini bisa digunakan untuk penelitian selanjutnya.

\section{DAFTAR PUSTAKA}

1. Junizar M. Benda Asing Esofagus. Dalam : Soepardi A. Efianty, Iskandar Nurbaiti, Bashiruddin Jenny, Restuti D. Ratna, Buku Ajar Ilmu Kesehatan Telinga Hidung Tenggorok Kepala \& Leher. Balai Penerbit FKUI. Jakarta. 2012; Edisi 7(1):266-69

2. Price AS, Wilson ML. Patofisiologi Konsep Klinis Proses-Proses Penyakit. Jakarta: EGC, 2005; Edisi
6(1):404-7

3. Herawati S Rukmini S, Buku Ajar Ilmu Penyakit Telinga Hidung Tenggorok. Jakarta: EGC, 2003. p:54-55

4. Uyemura MC. Foreign Body Ingestion in Children. American Family Phisician. 2005;72(2): 187-91

5. Gilyoma JM, Chalya PL. Endoscopic Prosedure of Foreign Body Removal of The Aerodigestive Tract: The Bugando Hospital Experience. BMC Ear, Nose, and Throat Disorder. 2011; 11(2): 2-5

6. Wadhera R, Gulati MS, Garg A, Ghai A. An Unusual Sharp Foreign Body Esophagus : A Razor Blade. The Internet Journal of Head and Neck Surgery. 2007; 2(1)

7. Nastia, Puja. Prevalensi Benda Asing Pada Telinga, Hidung, Trakeobronkial, dan Esofagus di Departemen THT FK USU/RSUP H Adam Malik tahun 2010. 2012; 2(1)

8. Guyton CA, Hall EJ. Buku Ajar Fisiologi Kedokteran. Jakarta: EGC, 200; Edisi 11(1):822-24

9. Adams LG, Boies RL, Higler HP. Esofagoskopi. In: Boies Buku Ajar Penyakit THT (edisi 6). Jakarta: EGC, 1997; 462-4.

10.Junizar M. Benda Asing Esofagus. In: Soepardi A. Efianty, Iskandar Nurbaiti, Bashiruddin Jenny, Restuti D. Ratna. Buku Ajar Ilmu Kesehatan Telinga Hidung Tenggorok Kepala \& Leher. Balai Penerbit FKUI. Jakarta. 2002; Edisi 5(1):245-51

11. Onyekwere GN, Onakoya PA, Olusola A S, Kokong DD, Oluwole OD. Esophageal impacted dentures. Journal of The National Medical Association. J Natl Med Assoc. Oct 2004; 96(10): 1350-3.

12.Eti V Upadhyaya, Punit Srivastava, Vijay D Upadhyaya, AN Gangopadhyay, SP Sharma. Double coin in esophagus at same location and same alignment - a rare occurrence: a case report. Cases Journal. 2009; 2:7758. 